\title{
Descriptions of New Species of Mollusca from the Northwest Coast of America.*
}

\author{
BY W. H. DALL, U. S. COAST SURVEY.
}

\section{Magasella Aleutica, Dall, n. s. (Pl. I, fig. 6).}

Shell small, nearly smooth, salmon colored, brighter on the lines of growth, and pale on the umbones; form subquadrate, anterior edge of hæmal valve very slightly excavated, and that of the neural valve correspondingly produced. Loop excessively slender, except the lateral arms of the reflexed portion, which are very broad, but connected behind by a very slender thread of shelly matter, the reflexed portion forming a sort of funnel, opening above, and almost incomplete behind. Septum thin, rather broad from behind forward, not produced above the reflexed portion of the loop. Cardinal process and hinge teeth small and inconspicuous, foramen incomplete and horse-shoe shaped, with no vestige of a deltidium. Lat. $\cdot 35$ in., alt. $\cdot 2$ in., lon. of neural valve $\cdot 37$ in., of hæmal valve $\cdot 33$ in.

Habitat, in the Alentian Ids, from Alsutan Pass, to the Shumagins, attached to the under surface of rocks at extremest low water of spring tides; Dall.

This pretty species resembles in miniature Laqueus rubella of Sowerby, but is proportionately shorter and broader. The animal is rather sluggish, and living specimens kept in sea water for several days exhibited no further signs of life, than the slight opening of the valves. The soft parts are of a darker reddish color, and show through the shell to some extent, as in Waldheimia venosa. There is some variation in form, some specimens being much broader than others. It was not uncommon, and a number of living specimens were obtained but the details of the anatomy are reserved for another paper to be prepared at a time when I may be able to devote more leisure to the subject.

Acmaa (Collisella) peramabilis, Dall, n. s.

Shell thin, delicate, ovate; externally of a uniform dark rose color, with a few scattered irregular blotches of light or dark brown, nucleus pale. Within polished, bluish white, with a chestnut brown spectrum with sharply defined edges, outside of which for a short distance the white is unsullied, but further toward the margin in adult specimens, radiating brown blotches may be observed forming a more or less interrupted baud around the shell, which is wanting in the young. The margin is of the same deep rose as the exterior. Shell moderately elevated, with the apex well marked subacute and situated in the central third. Nucleus smooth, pale, sharply decurved with a chink beneath it, in front. Sculpture of fine sharp elevated threads which extend from the vertex to the margin without bifurcating. 'These are crossed by very fine sharp lines of growth slightly elevated. Lou. 1.03 in., lat. 0.8 in., alt. 0.33 in. Posterior slope slightly arched.

Habitat, Shumagin group of islands, Alaska Territory, on rocks near low water mark. Dall. 
This lovely species has no relations with $A$. sybaritica, Dall, and rosacea, Cpr., except those of color. The two latter are much smaller and the rose color is much lighter and differently disposed. Its nearest allies are some varieties of $A$. patina, in none of which have $\mathrm{I}$ observed any approach $t_{o}$ the color of this species, and which have a different nucleus, and the sculpture in slender rounded riblets instead of sharp threads. The shell of patina is also in general much more solid and thick. The animal partakes of the rosy hue of the shell except the margin of the mantle which is furnished with brown dots. It belongs to the subgenus Collisella. It is worthy of note that when there is a brown marking on the exterior, in the region of the submarginal internal mottled band, the latter is interrupted by a white space corresponding in size and width to the external marking. In spite of the very great variations in the species of this genus, I feel sufficiently confident in regard to the distinctness of this form to describe it as a well marked species, excelled in beauty by none.

Argonauta expansa, Dall, n. s.

Shell of moderate size, of nearly two involute whorls. Aperture widely expanded near the spire, rather narrow in front. Carinæ rather blunt, furnished with about thirty alternate projections, those behind the posterior edge of the aperture above and below, being tipped with very dark brown. The prominence of the projections decreases in the middle of the back, and they become larger and more prominent toward the anterior edge of the aperture. The prominence of the lateral radiating folds varies in like manner. Of these about twenty-three start from the axis of the shell, which is drawn out behind the lateral expansions of the aperture and supports them. There are about twentysix intercalary folds. The spire behind the posterior edge of the aperture is more or less tinged with brown, and there is a livid brownish purple coloration on the lateral extensions of the axis and that part of the shell adjacent to them. The interior of the shell is smoothly polished, the exterior, especially on the protuberances of the carinæ, is covered with a multitude of exceedingly minute rough pustules, which give a very rough, harsh feel to the shell, and under a lens appear hemispherical. Laying the shell upon its aperture, with the apex posterior, we have the following measurements. Total length $3.25 \mathrm{in}$. Width of dorsal area posteriorly 0.32 in., do. anteriorly 0.7 . Height of shell 2.0 inches. Total extension of axis from end to end. 4 inches. Total length of aperture $2 \cdot 25$ inches, length from the anterior edge of the spire to the anterior edge of the aperture 1.9 inches.

Habitat, in the Gulf of California.

This pretty and peculiar argonaut possesses an assemblage of characters not common to any described species, though there are several which have a somewhat similar lateral extension of the axis. The dry ova still adhere to the inner side of the spire, and the shell is evidently fresh. I have seen one other specimen smaller than the one described, and collected at the same time. The only other species known from the same locality, (A. Pacifica, Dall,) is much compressed, has not the lateral extensions and has a different sculpture, beside growing much larger. Colls. Stearns, Dall, Fisher and Harford. 


\section{$2 \mathrm{BHL}$ Biodiversity Heritage Library}

Dall, William Healey. 1872. "Descriptions of new species of Mollusca from the northwest coast of America." Proceedings of the California Academy of Sciences 4, 302-303. https://doi.org/10.5962/bhl.part.14388.

View This Item Online: https://www.biodiversitylibrary.org/item/22481

DOI: https://doi.org/10.5962/bhl.part.14388

Permalink: https://www.biodiversitylibrary.org/partpdf/14388

\section{Holding Institution}

MBLWHOI Library

\section{Sponsored by}

MBLWHOI Library

\section{Copyright \& Reuse}

Copyright Status: NOT_IN_COPYRIGHT

This document was created from content at the Biodiversity Heritage Library, the world's largest open access digital library for biodiversity literature and archives. Visit BHL at https://www.biodiversitylibrary.org. 